\title{
Paradigma Terminologi Islam (Muslim) Dan Iman (Mukmin) Atas \\ Larangan Pernikahanantar-Agama \\ Dalam Hukum Islam
}

\author{
Sadari \\ Institut Agama Islam Shalahuddin Al-Ayyubi \\ (INISA) \\ Tambun-Bekasi \\ arifahmikhan@gmail.com
}

\begin{abstract}
Debates in theological terms have been occurred among the historical Civilization of Islami. As well as in terms of Islamic law, which have continually developed. This article examines how terms with theological nuances are integrated or at least interconnected. This article examines how the terms Islam (muslim) and Iman (mukmin) are linked to the law on the prohibition of interfaith marriage. This is very interesting, because there has been an resistance to an exciting laws had been replaced by a new that recently created, then those that already exist are replaced by recently created. By using Muhammad Syahrur's paradigm, the article examines more and deeper in the location key of the different meanings of the terms and develooing idioms that devel which are background to the prohibition of interfaith marriage, such as musyrik, kafir, Ahl al-Kitāb, Islam, and iman, so that the formula that will be researched is How to find Muhammad Syahrur's paradigm to the term or term for the prohibition of interfaith marriage, then to find out the effects of that and formulate how the law applies to the prohibition of interfaith marriage in Islamic law. The direction of this study uses normative-historical, which tries to find out what kinds of structures that can build an interfaith marriage discourse. By examining and addressing these methods and components to create power relations in the interfaith marriage discourse. It is hoped will be useful for the creation of a more precise understanding and in the end it may contribute the ideas in a broad horizon of knowledge, especially in Islamic family law.
\end{abstract}

Keywords: Paradigm; Interfaith Marriage; Islamic law

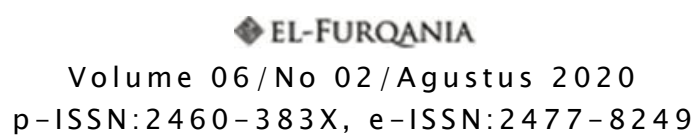




\begin{abstract}
Abstrak Perdebatan dalam terma teologis sudah terjadi pada alam sejarah peradaban Islam, begitupun dalam terma hukum Islam, secara terus-menerus mengalami perkembangan. Artikel ini mengkaji bagaimana antara terma yang bernuansa teologis terintegrasi atau minimal terinterkoneksi. Artikel ini mengkaji bagaimana terma Islam (muslim) dan Iman (mukmin) dikaitkan dengan hukum atas larangan pernikahan antar-agama. Ini sangat menarik, karena adanya tolaktarik hukum yang sudah ada, kemudian yang hukum sudah ada terasa tergantikan dengan hukum yang baru saja ditelurkan. Dengan menggunakan paradigma Muhammad Syahrur artikel menelaah lebih dalam pada letak kunci berbedaan makna atas term-term atau istilahistilah yang berkembang yang melatarbelakangi larangan pernikahan antar-agama, seperti musyrik, kafir, ahli kitab, Islam, dan iman, sehingga formula yang akan dikaji adalah menemukan paradigma Muhammad Syahrur itu terhadap term atau istilah atas pelarangan pernikahan antar-agama, kemudian untuk mengetahui pengaruhnya atas pernikahan antar-agama dan merumuskan bagaimana penerapan hukum atas pelarangan pernikahan antar agama dalam hukum Islam.Arah kajian ini menggunakan normative-historis, yang berusaha mengetahui apa saja dari struktur-struktur yang dapat membangun sebuah wancana pernikahan antar-agama. Dengan mengkaji dan menyikapi metode-metode dan komponen-komponen tersebut hingga membuat relasi kuasa dalam wancana pernikahan antar-agama. Hal ini diharapkan berguna demi terciptanya pemahaman yang lebih tepat dan pada akhirnya nanti bisa memberikan sumbangsih pemikiran dalam cakrawala ilmu yang sangat luas, khususnya pada hukum keluarga Islam.
\end{abstract}

Kata Kunci: Paradigma; Pernikahan Antar Agama; Hukum Islam

\title{
Prolog
}

Di era globalisasi sekarang ini dan gencarnya isu pluralisme, masyarakat hidup dalam pondasi dan lingkungan sosial plural yang telah melampaui sekat etnis, budaya, serta agama. Atas dasar itulah untuk tetap menyelanggarakan kehidupan yang hamonis dalam berkeluarga, perlu dituntut untuk senantiasa mampu menghadapi realitas kebhinekaan (pluralism) tersebut. Dari sinilah muncul kegelisahan terhadap permasalahan pernikahan antar-agama, ketika para fuqaha dan para ulama masih duduk manis di mimbar pengajian 
atau majelis dengan fatwanya yang mengatakan bahwa pernikahan agama adalah sesuatu yang diharamkan.

Salah satu masalah pokok yang menjadi problem dalam merajut hubungan antar-umat beragama dalam Islam adalah menyangkut terminologi Ahl al-Kitāb. Di dalam al-Qur'an, term Ahl al-Kitāb menunjukan kepada suatu komunitas Yahudi dan Nasrani. ${ }^{1}$ Meski demikian, term Ahl al-Kitāb masih sering dikonotasikan dengan kelompok yang sesat, suka melakukan perubahan dan penyelewengan terhadap kitab sucinya.

Abū al-'Alā al-Maudūdi menuturkan, buka dan bacalah alQur'an dari awal, mulai dari surat al-Fätihah, sampai akhirnya, surat al-Nās, akan ditemukan katagori kepercayaan istilah-istilah yang antara satu dan lainnya, arti dalam maknanya berbeda, yakni term istilah Mushrik, istilah Ahl al-Kitāb, dan istilah Ahl al-Imān. ${ }^{2}$

Menurut Arkoum, Ahl al-Kitäb, yang merujuk kepada kelompok, yang merujuk kepada kelompok Yahudi dan Nasrani adalah sifatnya kontekstual maka defininya bisa ditransformasikan secara didamis. Sehingga makna teks Ahl al-Kitāb ini perlu dibongkar karena masih menyisahkan makna polemis dan pertentangan teologis. Artinya makna teks Ahl al-Kitāb ini mengundang paham eksklusifis yang lebih mengendepankan "Arena pertandingan kebenaran" dengan mencari justifikasinya dari agama, untuk itu maka perubahan paradigma (shift paradigm) dari Ahl alKitāb ke konsep Masyarakat Kitab dianggap perlu agar dapat melucuti perbagai faktor penghalang dalam penentuan hukum termasuk discourse pernikahan antar-agama. Dalam hal ini Arkoun ingin mengatakan bahwa pada intinya ingin membangun sebuah gagasan yang sesuai dan selaras dengan inklusifisme beragama.

Nampaknya persepsi Arkoun sama dengan Muhammad Syahrur yakni, sangat dipengaruhi oleh salah satu kelompok umat Islam yang ia anggap rigid dalam memahami teks-teks wahyu. Tapi ternyata Arkoun melangkah lebih jauh lagi, ia dengan konsep dekontruksinya itu yang ingin mengikis klaim teks teologis yang menyatakan "hanya Islamlah satu-satunya agama yang benar."

Akan tetapi terbukti, selama ini masih ada ambivalensi dalam frame hubungan antara-umat beragama dalam arti bahwa komunikasi

\footnotetext{
${ }^{1}$ QS. Ali Imran (3): QS. al-Maidah (5): 48. QS. ash-Shaff (61):6.

${ }^{2} \mathrm{Abu}$ al-A'la al-Maududi, al-Islamfi Maqajahah al-Tahaddiyah al-Mu'assharah, (Kuwait: Dar al-Qalam, 1983), 112.
} 
pengikut Agama yang berbeda hanya mau bertoleransi dalam wilayah sosial, dan tidak ada toleransi dalam wilayah tepologi-doktrinal. Oleh karena itu, ketika aspek doktrinal tersebut meminta pengejawantahannya dalam lapangan praktis, seperti pernikahan, maka yang terjadi adalah "kepengecutan".

Ambivalensi tersebut muncul karena pendekatan yang digunakan masih membedakan antara yang sacral dan yang profane. Padahal kedua hal tersebut saling terkait erat. Jika secara teologis disepakati bahwa sebuah wacana pluralis yang pro existence maka secara muamalah pun seharusnya memiliki landasan yang kuat untuk applicability. Karena itu, sebenarnya tidak ada larangan untuk melintas batas agama dalam bidang pernikahan. ${ }^{4}$

Pernikahan antar-agama adalah hal yang sangat rumit, dalam banyak kasus di masyarakat kita masih muncul resistensi yang begitu besar terhadap pernikahan antar-agama. Umumnya, dalam persoalan halal-haramnya pernikahan antar umat beragama, ${ }^{5}$ karena para ulama selalu berpegang pada ayat-ayat al-Qur'an seperti yang dikutip di bawah ini:

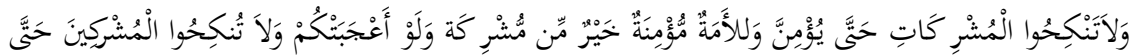

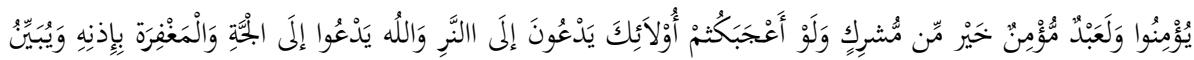

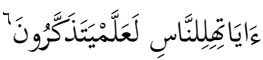

Artinya: "Dan janganlah kamu menikahi wanita-wanita musyrik, sebelum mereka beriman. Sesungguhnya wanita budak yang mukmin lebih baik dari wanita musyrik, walaupun dia menarik hatimu. Dan janganlah kamu menikahkan orang-orang musyrik (dengan wanita-Wanita mukmin) sebelum mereka beriman. Sesungguhnya budak yang mukmin lebih baik dari orang musyrik, walaupun dia menarik hatimu.Mereka mengajak ke neraka, sedang Allah mengajak ke surga dan ampunan dengan izin-Nya. Dan Allah menerangkan ayat-ayat-Nya (perintah-perintah-Nya) kepada manusia supaya mereka mengambil pelajaran."

\footnotetext{
3 Suhadi “Kawin Lintas Agama: perspektifm Kritik Nalar Islam (LKis, Yokyakarta: 2006), vi.

4 Suhadi “Kawin Lintas Agama: perspektif Kritik Nalar Islam (LKis, Yokyakarta: 2006), vi.

5 Sadari, Konsepsi Pernikahan Relevansi Antara Agama dan Keberagamaan: Refleksi Pemikiran Hukum Keluarga Islam, cet. ke-1, (Pondok Cabe Tangsel: CV. Iqralana, 2018).

${ }^{6}$ QS. al-Baqarah (2): 221.
} 


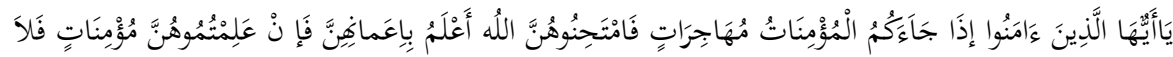

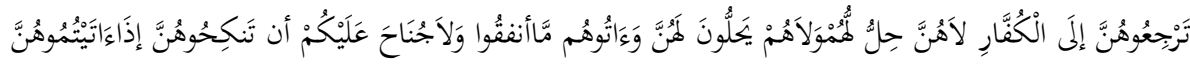

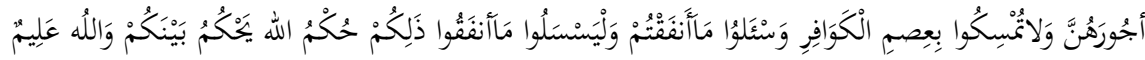

$$
\begin{aligned}
& \text { حَكِيم آحردين }
\end{aligned}
$$

Artinya: "Wahai orang-orang yang beriman! Apabila perempuan-perempuan mukmin datang berhijrah kepadamu, maka hendaklah kamu uji (keimanan) mereka. Allah lebih mengetahui tentang keimanan mereka; jika kamu telah mengetahui bahwa mereka (benar-benar) beriman maka janganlah kamu kembalikan mereka kepada orang-orang kafir (suami-suami mereka). Mereka tidak halal bagi orang-orang kafir itu dan orang-orang kafir itu tidak halal bagi mereka. Dan berikanlah kepada (suami) mereka mahar yang telah mereka berikan. Dan tidak ada dosa bagimu menikahi mereka apabila kamu bayar kepada mereka maharnya. Dan janganlah kamu tetap berpegang pada tali (pernikahan) dengan perempuan-perempuan kafir; dan hendaklah kamu minta kembali mahar yang telah kamu berikan; dan (jika suaminya tetap kafir) biarkan mereka meminta kembali mahar yang telah mereka bayar (kepada mantan istrinya yang telah beriman). Demikianlah hukum Allah yang ditetapkan-Nya di antara kamu. Dan Allah Maha Mengetahui, Mahabijaksana."

Ayat-ayat diatas ayat Madaniah yang pertama kali turun dan membawa pesan khusus agar orang-orang Muslim tidak menikah wanita musyrik atau sebaliknya. Imam Muhammad al-Rāzi dalam alTafsir al-Kabir-nya Mafatih al-Gaib menyebut ayat tersebut sebagai ayat-ayat permulaan yang secara eksplisit menjelaskan hal-hal yang halal (mā yuhallu) dan hal-hal yang dilarang (mā yuhramu). ${ }^{8}$ Dan, menikahi orang musyrik merupakan salah satu perintah Tuhan dalam kategori "haram" dan "dilarang".

Berbeda dengan pandangan dan pendapat para ulama di atas, Islam liberal mengatakan bahwa tentang pernikahan muslim dan nonMuslim, pada intinya dibolehkan dengan alasan: ${ }^{9}$

\footnotetext{
${ }^{7}$ QS. al-Mumtahanah (60): 10.

${ }^{8}$ Imam Muhammad Fakhruddin al-Rāzìi. Tafsir al-Fakhr al-Rāzì al-Mushtahar bi al-Tafsir al-Kabïr wa Mafätih al-Ghaib, dikomentari oleh Syaikh Khabil Muhyiddin al-Mays, jilid v (Beirut: Dār al-Fikr, 1995), 59.

9 Nurcholis Madjid, et.al, Fikih Lintas: Membangun Masyarakat InklusifPluralis (Jakarta: Paramadina, 2004)., 2004), 160-2.
} 
Pandangan pertama, tidak boleh mencampur adukan arti antara Musyrik dengan Ahl al-Kitäb, bila Allah melarang mengawini perempuan Musyrik, seperti yang terdapat pada surat al-Baqarah 2: 221, "Janganlah kamu menikah dengan perempuan-perempuan Musyrik sebelum beriman" tidak tepat bila dipahami yang dimaksud dengan perempuan Musyrik adalah Ahl al-Kitāb. Yang dimaksud dengan Musyrik di situ sama sekali bukan Yahudi dan Nasrani, tapi orang Musyrik Arab yang tidak punya kitab suci.

Pandangan kedua, Larangan menikahi Musyrik laki-laki maupun perempuan karena dikhawatirkan memerangi umat Islam, kita tahu bahwa ayat ini diturunkan dalam situasi ketegangan antara umat Islam dengan orang Musyrik Arab. Dengan demikian makna Musyrik lebih mengarah pada mereka yang suka memerangi umat Islam.

Pandangan ketiga, Musyrik sepertinya murni sebagai kekuatan politik, di antara ambisinya adalah kekuasaan dan kekayaan. Sedangkan Yahudi dan Nasrani adalah mereka yang sedikit banyak mempunyai persinggungan teknologi dengan Islam.

Pandangan keempat, Alasan yang fundamental tentang dibolehkannya pernikahan antara agama, terutama dengan nonMuslim, yaitu ayat yang berbunyi: "Hari ini telah dihalalkan kepada kalian segala yang baik, makanan ahli kitab dan makanan kalian juga hal bagi ahli kitab, begitu juga wanita-wanita janda mukmin dan ahli kitab sebelum kalian."10

Dari sekian keberagamaan pandangan dan pendapat hukum tentang pernikahan antar-agama, artikel ini secara konsisten meminjam konsep paradigma yang dikembangankan oleh Syahrur. Seorang insinyur berkembangsaan Syria dan salah satu tokoh kontroversial yang muncul pada penghujung abad ke-20-an, ${ }^{11}$ Syahrur

\footnotetext{
${ }^{10}$ QS. al-Māidah (5):5.

${ }^{11}$ Beliau dilahirkan pada tahun 1983. Setelah tamat sekolah menengah atas pada umur 19 tahun, beliau berangkat ke Moskow untuk mempelajari engineering. Pada tahun 1964 beliau kembali ke Syiria, dan pergi lagi pada tahun 1968 menuju University College di Dublin, Irlandia untuk menempuh program Master (S2) dan Doktor (S3) dalam bidang perminyakan (soil mechanics) dan Tehnik bangunan (faundation engineering). Sejak tahun 1972 beliau menjadi staf pengajar di Universitas Damaskus hingga sekarang. Di antara karya ialah al-Kitāb wa alQur'ān, dirāsah Islāmiyyah Mu'asirah fì al-Dawlah wa al-Mujtama', dan al-Islām wa al-Imān: Manzūmah al-Qiyam. Ketiga buku tersebut diterbitkan oleh Dār alAhali li al-Tibā'ah wa al-Nashr wa al-Tawzì', masing-masing pada tahun 1990 ,
} 
tentu tidak menyediakan sebuah "konsep" yang "jadi". Sehingga harus menginventaris tulisannya dari berbagai buku dan artikel baik yang berbahasa Arab, Inggris atau bahkan terjemahan dalam bahasa Indonesia. Setelah itu baru kemudian merekontruksinya menjadi rumusan konsep yang bisa terapkan untuk menganalisa sebuah persoalan.

Tipologi penafsiran kontemporer setiap tipe pemahaman para ulama terhadap teks al-Qur'an sangat beragam sesuai dengan keberagaman metode, pendekatan dan asumsi hermeneutis yang dipakai dalam menafsirkan al-Qur'an. Menurut Sahiron Syamsuddin secara singkat menjelaskan ada tiga tipe besar penafsiran ditinjau dari sisi obyektivitas dan subyektivitas penafsiran. Tiga tipe yang dimaksud adalah sebagai berikut. ${ }^{12}$

Pertama, pandanganquasi-obyektivis tradisionalis, yang dimaksud dengan pandangan quasi-obyektivis tradisionalis adalah suatu pandangan bahwa ajaran-ajaran al-Qur'an harus dipahami, ditafsirkan dan diaplikasikan pada masa kini, sebaga mana ia pahami, ditafsirkan dan diaplikasikan pada situasi, di mana al-Qur'an diturunkan kepada Nabi Muhammad Saw dan disampaikan kepada generasi Muslim awal. Umat Islam yang mengikuti pandangan ini, seperti Ikhwanul Muslimin di Mesir dan kaum Salafi di beberapa Negara Islam, berusaha menafsirkan al-Qur'an dengan bantuan berbagai perangkat metodis ilmu tafsir klasik, seperti ilmu asbāb alnuzūl, ilmu munāsabah al-ayat, ilmu tentang ayat-ayat muhkam dan mutashäbih, dan lainnya.

1994 dan 1996.Beliau juga aktif menulis artikel dibeberapa majalah dan jurnal, seperti "The Divine Teks and Pluralism in Muslim Societies" dalam Muslim Politics Report 14 (Agustus, 1997), 3-9, "Islam and the 1995 Beijing Word Conference on Women" dalam Kuaitin Newspaper, kemudian diterbitkan pula dalam buku Liberal Islam, ed.Charles Kuzman (New York dan Oxford: Oxford University Press, 1998). Selain itu, Syahrur sering mempersentasikan pokok-pokok pikirannya tentang al-Qur'an kaitannya dengan masalah-masalah sosial dan politik, seperti hak-hak wanita, pluralism dalam banyak konfrensi Internasional, antara lain MESA Conference tahun 1998 di Chicago (MESA Newsletter 2003, Agustus, 1998).

12 Sahiron Syamsuddin, "Tipologi dan Proyeksi Penafsiran Kontemporer terhadap al-Qur'an" dalam jurnal Studi Ilmu-ilmu al-Qur' an dan Hadis vol.8, No.2, Juli 2007. Lihat pembahasan terperinci tentang ketiga pendapat tersebut di dalam disertasinya yang berjudul "Muhammad Shahrur Koran Hermeneutik und die Debatte um sie bei muslimichen"(segera terbit), 40-66. 
Kedua, pandangan quasi-obyektivis modernis, pandangan quasiobyektivis modrenis memiliki kesamaan dengan pandangan quasiobyektivis tradisionalis dalam hal bahwa mufassir di masa kini tetap berkewajiban untuk menggali makna asal dengan menggunakan di samping perangkat metodis ilmu tafsir, juga perangkat-perangkat metodis lain, seperti informasi tentang konteks sejarah makro dunia Arab saat penurunan wahyu, teori-teori ilmu bahasa dan sastra modern dan hermeneutika. Hanya saja, aliran quasi-obyektivis modernis yang diantaranya dianut oleh Fazlur Rahman dengan konsepnya double movement, ${ }^{13}$ Muhammad al-Tăalibì dengan konsepnya al-tafsìr al-maqāsid ${ }^{14}$, dan Nashr Hamid abu Zayd dengan konsepnya al-Tafsìr al-Siyaqui ${ }^{-15}$, memandang makna asal (bersifat histories) hanya sebagai pijakan awal bagi pembacaan al-Qur'an di masa kini; makna asal literal tidak lagi dipandang sebagai pesan utama al-Qur'an. Bagi mereka, sarjana-sarjana Muslim saat ini harus juga berusaha memahami makna di balik pesan literal, yang disebut oleh Rahman dengan ratio legis, dinamakan oleh al-Ṭālibỉ dengan maqāsid (tujuan-tujuan ayat) atau disebut oleh Abu Zaid dengan mahza (signifikansi ayat). Makna di balik pesan literal inilah yang harus diimplementasikan pada masa kini dan akan datang.

Ketiga, pandangan subyektivis, berbeda dengan pandanganpandangan tersebut di atas, aliran subyektivis menegaskan bahwa setiap penafsiran sepenuhnya merupakan subyektivis penafsiran,dan arena itu kebenaran interpretatif bersifat relatif. Atas dasar ini, setiap generasi mempunyai hak untuk menafsirkan al-Qur'an sesuai dengan perkembangan ilmu dan pengalaman pada saat al-Qur'an ditafsirksan.

Pandangan seperti ini antara lain dianut oleh Syahrur. Dia tidak lagi tertarik untuk menelaah makna asal dari sebuah ayat atau kumpulan ayat-ayat. Mufassir modern, menurutnya, seharusnya menafsirkan al-Qur'an sesuai dengan perkembangan ilmu modern, baik itu ilmu eksakta maupun non-eksakta. Syahrur menegaskan bahwa kebenaran interpretatif terletak pada kesesuaian sebuah penafsiran dengan kebutuhan dan situasi serta perkembangan ilmu pada saat al-Qur'an ditafsirkan dalam hal ini dia berpegang pada

\footnotetext{
${ }^{13}$ Rahman, Islam and Modernity., 5.

${ }^{14}$ al-Thalibi, 'Iyal Allah (Tunisi: Saras li al-Nasyr, 1992), 142-144.

${ }^{15}$ Abu Zayd, al-Nas, al-Sultah, al-haqīqah (Beirut: al-Markaz al-Saqafī al' Arabī, 1995), 116
} 
adagium: thabat al-nas wa haraqat al-muhtawā(teks al-Qur'an tetapi, kandungannya terus bergerak atau berkembang).

Bedasarkan tipologi penafsiran ini, ketertarikan muncul pada tipologi yang ketiga dengan tokohnya adalah Syahrur, dikarenakan objek kajian dalam buku-buku Syahrur adalah mendeskripsikan bahwa saat ini terjadi fenomena melemahnya ilmu-ilmu uṣulluddin atau yang lebih dikenal dengan ilmu-ilmu al-shar'iyyah, sebagai lawan dari "ilmu-ilmu umum". ${ }^{16}$ Dengan demikian, tidaklah berlebihan bila Syahrur juga mengatakan bahwa dekadensi yang dialami oleh fiqh Islam dewasa ini di duga juga disebabkan oleh telah usangnya perangkat teoritis ilmu ușūl fiqh. Bahwa persis fiqh dewasa ini lebih disebabkan oleh kesalahan metodologis, yang tiada lain adalah kesalahan ilmu ini, bukan kelemaham bahasa Arab atau indahnya ketakwaan umat Islam. $^{17}$ Terbukti walaupun bahwa dinamika penafsiran al-Qur'an tidak pernah mengalami kemandekan sejak kitab suci tersebut diwahyukan kepada Nabi Muhammad Saw, dan dengan berbagai macam corak penafsrian ditawarkan oleh para musafir, baik klasik maupun modern, ${ }^{19}$ namun masih menyisahkan banyak permasalahan dan perdebatan hukum yang susah untuk diterapkan dalam kehidupan dewasa ini, termasuk dalam penerapan pernikahan antar-agama.

Menurut Syahrur seharusnya studi terhadap al-Qur'an dan metodologi tafsir selalu mengalami perkembangan yang signifikan, seiring dengan akselarasi perkembangan kodisi sosial budaya dan peradaban manusia, sejak turunya al-Qur'an hingga sekarang. Fenomena tersebut merupakan konsekuensi logis dari adanya keinginan umat Islam untuk selalu mendialogkan antara al-Qur'an bagai teks (nas) yang terbatas, dengan perkembangan problem sosial kemanusiaan yang dihadapi manusia sebagai konteks (waqa'ī) yang terbatas. Hal itu juga merupakan salah satu implikasi dari pandangan teologis umat Islam bahwa al-Qur'an itu șălihun li kulli zamān wa makān, (al-Qur'an itu selalu cocok untuk setiap waktu dan tempat).

\footnotetext{
${ }^{16}$ Muhammad Syahrur, Nahw Ușūl al-Jadidah li al-Fiqh al-Islām (Damaskus: alAhali li al- tibā'ah wa al-Nashr wa al-tauzi', 2000), 45-6.

17 Lihat Muhammad Syahrur, al-Kitāb wa al-Qur'ān: Qirā'ah Mu'āsirah (Damaskus: al-Ahali li ath-thiba'ah wa al-Nashr wa al-tauzi'”, 1992), 579.

${ }^{18}$ Amin al-KhūIi, Manāhij Tajdid fì al-Nahw wa al-Balāghah wa al-Tafsìr wa alAdab (Kairo: Dār al-Ma'rifah, 1961), 302.

${ }^{19}$ M.Husayn al-Dhahabi, al-Tafsir wa al-Mufassirūn, (Beirut: Dār al-Kutub alHadithsah, 1961).
} 
Karenanya, sebagaimana dikatakan Syahrur, al-Qur'an harus selalu dengan tututan era kontemporer yang dihadapi umat Islam. ${ }^{20}$

Oleh karenanya, suatu penafsiran tidak hanya bersifat reproduktif, melainkan juga produktif, yakni makna teks tidak harus makna bagi pengarangnya, melainkan makna bagi manusia yang hidup di zaman ini, maka menafsirkan adalah proses kreatif. Sejalan dengan pandangan ini, Syahrur menyatakan bahwa ada pertautan segitiga antar-turats (produk pemikiran masa lalu seperti teks), kekinian (mu'asirah) dan otentisitas (al-Așalah), ${ }^{21}$ dengan sepirit semacam itulah maka al-Qur'an selalu sālihun li kulli zamān wa makān. $^{22}$

Ketertarikan dalam penulisan ini juga terletak pada paradigma pemikirannya yang bertitik tolak dari asumsi bahwa "tidak ada sinonim dalam bahasa" Syahrur mulai mengelaborasi setiap kata kunci yang terdapat dalam al-Qur'an. ${ }^{23}$ Dalam hal ini, Syahrur sepakat dengan Ibnu Fāris yang menyatakan bahwa di dalam bahasa Arab tidak terdapat sinonim (murādif), setiap kata mempunyai kekhususan makna. Satu kata bahwa bisa jadi memiliki lebih dari satu potensi makna (polifalen/beragam) ${ }^{24}$ termaksud istilah-istilah seperti: musyrik, kafir, ahli kitab, dan Islam, iman yang tentunya term-term itu adalah istilah yang sulit dan bertingkat yang perlu dikaji lebih mendalam yang berkaitan pula pada permasalahan hukum pernikahan antar-agama.

Syahrur, sebagai seseorang yang mendapatkan gelar doktor di bidang teknik, setelah menekuni filsafat dan linguistik, mencoba merambah wilayah 'Ulüm al-Qur'ān. Tepatnya setelah ia meluncurkan karya magnum opusnya al-Kitāb al-Qur'ān: Qirā'ah $M u$ 'asirah yang menggunakan pendekatan linguistik modern. Dalam buku ini Syahrur sering menggunakan metefora dan analogi dari ilmu teknik dan sains. Syahrur berusaha melakukan dekontruksi sekaligus

\footnotetext{
${ }^{20}$ Muhammad Syahrur, al-Kitāb wa al-Qur'ān: Qirā'ah Mu'āsirah (Damaskus: al-Ahāli li al-țibā' ah wa al-Nashr wa al-tauzi', 1992), 33.

${ }^{21}$ Muhammad Syahrur, al-Kitāb wa al-Qur'ān: Qirā'ah Mu'āsirah (Damaskus: al-Ahāli li al-țibā' ah wa al-Nashr wa al-tauzì', 1992), 33.

${ }^{22}$ Muhammad Syahrur, al-Kitāb wa al-Qur'ān: Qirā'ah Mu'āsirah (Damaskus: al-AhāTi li al-tibā'ah wa al-Nashr wa al-tauzi'’, 1992), 32-33.

${ }^{23}$ Muhammad Syahrur, al-Kitāb wa al-Qur'ān: Qirā'ah Mu'āsirah (Damaskus: al-Ahāli li al-tibā' ah wa al-Nashr wa al-tauzì', 1992), 19.

${ }^{24}$ Muhammad Syahrur, al-Kitāb wa al-Qur'ān: Qirāah Mu'āsirah (Damaskus: al-Ahā̄i li al-țibā'ah wa al-Nashr wa al-tauzi', 1992), 196
} 
rekontruksi terhadap bagi konsep, teori dan paradigma yang telah mapan mainstream pemahaman, pemikiran bahkan keyakinan mayoritas umat Islam. ${ }^{25}$

Syahrur dalam bukunya "Prinsip dan Dasar Hermeneutika alQur'an Kontemporer", menyatakan bahwa al-Qur'an merupakan kitab berbahasa Arab otentik yang memiliki dua sisi kemukjizatan yakni: sastrawi dan ilmiah. Untuk memahami aspek sastrawi alQur'an perlu digunakan pendekatan deskriptif-signifikatif, sedang aspek ilmiahnya harus dipahami dengan pendekatan historis ilmiah, yang keduanya diletakkan dalam bingkai studi lingustik. Syahrur mengembangankan metode memahami al-Qur'an dengan istilah yang disebut manhaj al-Tartil yang dapat diidentikan dengan metode intratekstualitas (hubungan antara teks tertentu dengan teks lainnya). ${ }^{26}$

Buku kedua Syahrur yang juga diterbitkan oleh al-Ahli pada tahun 1994 berjudul: Dirāsăt Islämiyyah Mu'āsirah fì al-Daulah wa al-Mujtama'. Dalam buku ini Syahrur menguraikan tema-tema sosial politik yang terkait dengan persoalan masyarakat dalam (alMujtama') dan Negara (al-Daulah).Dengan tetap berpijak pada tawaran metologisnya dalam memahami al-Qur'an, sebagaimana buku pertamanya, secara kosisten Syahrur membangun konsep keluarga, masyarakat Negara dan tindakan kesewenang-wenangan (otoriter/al-istibdād) dalam perspektif al-Qur'an. Di samping itu, dalam buku ini Syahrur menguraikan berbagai tanggapan atas buku pertamanya seraya menegaskan bahwa ia berbeda dengan mereka dalam metodologi. ${ }^{27}$

\footnotetext{
${ }^{25}$ Rudy Al-Hana, “Paradigma Hermeneutika Dalam Tafsir al-Qur'an”, dalam Qalita Ahsan, Vol.VIII, No.1, April 2006, 91.

26 Muhammad Syahrur, "Prinsip dan dasar Hermeneutika al-Qur'an Kontemporer”, terj. Sahiron Samsudddin, et.al (Yogyakarta: eLSAQ Press, 2004), $\mathrm{xx}-\mathrm{xxi}$.

${ }^{27}$ Syahrur mengelompokan mereka ke dalam tiga golongan: pertama, golongan yang menanggapinya secara emosional dengan suara lantang tetapi tidak memiliki kecakapan ilmiah yang memandai, golongan ini dianjurkan belajar kembali secara serius. Kedua, golongan yang hanya memperhatikan bentuk (hasil) dan tidak memahami metodologi. Ketiga, golongan yang benar-benar serius dan layak mendapat pujian, yaitu golongan yang seperti hanya dihuni oleh Nasr Hamid Abu Zaid. Lihat Muhammad Syahrur, Dirāsāt Islāmiyyah Mu'āsirah fì ad-Dawlah wa alMujtama' (Damaskus: al-AhāTi li al-Ṭibā' ah wa al-Nahsr wa al-Tawzì', 1994), 3235 .
} 
Di tahun 1996, Syahrur meluncurkan buku kegiatannya yang berjudul al-Islām wa al-İmān: Manzümah al-Qiyam. Buku ini juga dicetak dan diterbitkan oleh al-Ahă $\bar{i}$. Buku ini mencoba mengkaji ulang konsep-konsep klasik mengenai rukun Isläm dan rukun Imān, sesutau yang paling mendasar dan paling dalam Islam. Melalui pelacakannya terhadap semua ayat al-Qur'an yang berkaitan dengan kedua konsep rukun dasar di atas, Syahrur ternyata menemukan konsep lain yang benar-benar berbeda dengan rumusan ulama terdahulu. $^{28}$

Dalam buku yang ketiga inilah tulisan ini lebih dalam lagi mengkaji dan menerapkan paradigma Syahrur atas larangan pernikahan antar-agama dalam hukum Islam. Atau dengan kata lain meminjam paradigma Syahrur dalam masalah hukum khususnya mengenai pernikahan antar-agama. Sepertinya Syahrur merasa tidak puas mengenai perdebatan makna pada dataran teologi-doktrinal yang mandeg (depend) pada trem Ahl al-Kitāb. Syahrur lebih dalam lagi mengkaji pada konsep Islam dan Iman, dalam menggali kedua konsep tersebut Syahrur menghimpun seluruh ayat yang menyebut dua terma itu berikut turunannya, sehingga dalam wilayah aqidah sampai pada sebuah tesis adanya kedua komunitas yakni Muslim dan Mukmin, yang disebut Mukmin adalah kaum yang mengikuti Muhammad, sedangkan orang Yahudi adalah Muslim Yahudi, orang Nasrani adalah Muslim-Nasrani.

Seorang yang disebut Muslim, kategori masyarakatnya hanya tiga hal: percaya atas eksistensi Allah, percaya akan adanya hari akhir dan beramal saleh. Hal yang terjadi adalah orang Muslim terkadang bukan orang Mukmin. Artinya seseorang yang mempercayai adanya Allah, hari akhir dan beramal saleh terkadang tidak mempercayai kerasulan Muhammad. Namun apabila menjadi orang Mukmin maka seseorang harus terlebih dahulu menjadi orang Muslim. Barang siapa

\footnotetext{
${ }^{28}$ Lima rukun Islam yang selama ini diyakni bersumber dari al-Qur'an dan alSunnah ternyata bagi Syahrur tentunya elaborasinya atas ayat-ayat al-Qur'an hanya kesaksian kepada Allah-lah (al-Syahadah al-Ülā) yang merupakan Islam di samping dua rukun Islam yang lainnya, yaitu percaya kepada hari akhir dan beramal shalih. Sementara kesaksian bahwa Muhammad utusan Allah dan empat rukun Islam sisanya, sebagaimana keyakinan umat Islam selama ini, dipahami oleh Syahrur sebagai rukun Iman dan bukan rukun Islam. Sesuatu yang benar-benar berbeda. Lebih jauh Baca ${ }^{28}$ Muhammad Syahrur, al-Islām wa al-Imān: Mandümat al-Qiyām (Damaskus: al-Ahā̄i li al-Tibā'ah wa al-Nashr wa al-Tawzì', 1996), 22, dan dalam bab I.
} 
yag melangkah ketingkatan Iman dengan melangkahi Islam termasuk "Munafiq", jadi Islam ialah batas minimalnya (al-had al-adnā) dalam bertauhid. Barangsiapa yang mendirikan shalat (rukun Iman) tanpa menetapi ajaran-ajaran rukun Islam termasuk Munafiq, sekalipun ia sujud, ruku', puasa dan pergi haji, iman inilah batas maksimalnya (alhad al-a'lā) dalam bertauhid kepada Allah Swt.

Sehingga kekafiran dan keberimanan seseorang bermakna dinamis, sedangkan kemusyrikan bisa dilihat objek material kemusyrikannya itu, kemusyrikan yang dilarang adalah kemusyrikan yang diiringi dengan tajsid yang ingin menjadikan Allah mushakhkhas. Bila dianalisis hal ini secara keseluruhan, secara logis dapat dipahami pernyataan Allah bahwa agama di sisi-Nya adalah Islam. Ia tidak menerima agama dari hamba-Nya yang tidak memiliki sumber. Sehingga akan tersadar bahwa ketika berbicara tentang Iman dan orang-orang beriman sesungguhnya dalamTanzīl al-Hakīm sedang berbicara tentang manusia, atau dua jenis iman. Pertama Iman kepada Allah dari Hari akhir (Islam), Kedua Iman kepada Muhammad dan risalahnya. Sehingga sampai pada titik ini kemudian Syahrur dalam Tanzîl al-Hakim meletakkan tiga pilar bagi Islam dan tujuh pilar Iman, yaitu: Pertama, Rukun Islam terdiri dari: (1) Iman sebagai penerimaan adanya eksistensi Allah, (2) Iman sebagai penerimaan atas hari akhir, (3) Amal Saleh. Kedua, Rukun Iman terdiri dari: (1)Bersaksi bahwa Muhammad adalah utusan Allah, (2) Mendirikan Shalat maktubah, dzikir kepada Allah, (3) Mengeluarkan Zakat (Infak), (4) Puasa Ramadhan (5), Pergi Haji bagi yang mampu, (6) Syura, (7) Jihad.

Sehingga dapat dinyatakan di sini bahwa menurut Syahrur umat Musa adalah Islam Yahudi dan umatnya Isa adalah Islam Nasrani sedangkan umatnya Muhammad adalah Mukmin. Sehingga bisa dikatakan bahwa tesis "Islam dibangun atas lima pilar" tidaklah valid, yang benar adalah Syahadat pertama.

1) Syahadat (pengakuan) bahwa Tuhan selain Allah $\rightarrow$ asas Islam $\rightarrow$ beribadah kepada Allah $\rightarrow$ Muslim.

2) Syahadat (pengakuan) bahwa Muhammad adalah utusan Allah $\rightarrow$ asas Islam $\rightarrow$ Mukmin.

Kaitannya dengan konsep Islam, Syahrur memulai dengan menganalisis tiga ayat, yakni: pertama, dalam QS. al-Ahzāb: 35 yang mengindikasikan adanya komunitas al-muslimūn wa al-muslimät (laki-laki dan perempuan muslimat) dan komunitass al-mu'minūn wa 
al- mu'mināt (laki-laki dan perempuan mukmin), kedua, dalam QS.alTahrim: 5 yang menyebutkan kata muslimāt (wanita muslim) yang disifati kata mu'mināt (beriman), ketiga dalam QS. al-Hujarāt: 14 yang menerangkan bahwa Nabi Muhammad Saw menyangkal pernyataaan sekelompok Badui yang mengatakan: "Kami telah beriman" dengan ungkapan Nabi yang berimplikasi bahwa mereka belum ber-iman, meski mereka telah ber-Islam.

Ketiga ayat tersebut dipahami Syahrur bahwa komunitas muslimūn-muslimāt itu bebeda dengan komunitas mu'minūnmu'minät, dan bahwa ke-islam-an seseorang itu datang lebih dulu dibanding ke-iman-annya. ${ }^{29}$

Menurut Syahrur, antonim dari kata Islam dalam al-Qur'an ialah kata ijräm. Dengan demikian, lawan kata muslimūn ialah mujrimūn. Kata ijrām dan turunannya disebut dalam al-Qur'an sebanyak 68 kali. Secara etimologis, kata ijräm berarti qat' (memutus/memotong). Dalam kamus hukum, pelaku kejahatan, seperti pencurian, pembunuhan dan perampokan, pelakunya berarti "memutuskan hubungannya dengan masyarakat dan aturan-aturan sosial dan bertindak sesuai dengan hawa nafsunya". Dalam al-Qur'an kata tersebut berarti kondisi yang bertolak belakang dengan Islam. Ayat-ayat, seperti QS. al-Qașaș: 78, QS. Yāsin: 59, QS. al-Rüm:12, QS. al-Rahmān: 41-43, QS. al-Naml: 69 dan QS. al-Mursalāt:18-19, mengaitkan secara sintagmatis kata al-mujrimūn dengan sikap pengingkaran terhadap adanya Tuhan dan Hari akhir. Hal ini menunjukan bahwa al-mujrimūn ialah mereka yang tidak percaya adanya Tuhan. ${ }^{30}$

Lebih komprehensif, QS al-Mudathir: 39-46 menerangkan bahwa mujrimūn ialah mereka, yang selain yang tidak beriman kepada Allah (lam naku min al-musallin, tidak memiliki silah/hubungan dengan Allah) dan Hari Akhir (nukadhdhibu bi yawm al-din), tidak berbuat kebajikan (lam naku nut'imu al-miskin), bahwa berbuat perilaku-perilaku yang dapat membahayakan orang lain (kunna nakhụ̣̈u ma'a al-khā'iḍin). ${ }^{31}$

\footnotetext{
${ }^{29}$ Muhammad Syahrur, al-Islām wa al-Īmān: Manzūmāt al-Qiyam (Damaskus al-AhāTi li al-Tibā'ah wa al-Nashr wa al-Tawzì',1996), 31.

${ }^{30}$ Muhammad Syahrur, al-Islām wa al-İmān: Manzümāt al-Qiyam (Damaskus al-AhāTi li al-Ṭibā'ah wa al-Nashr wa al-Tawzi', 1996), 39-40.

${ }^{31}$ Muhammad Syahrur, al-Islām wa al-İmān: Manzūmāt al-Qiyam (Damaskus al-Ahāli li al-Ṭibā'ah wa al-Nashr wa al-Tawzì',1996), 41.
} 
Di sini tampak jelas bahwa Syahrur menggunakan teori paradigm-sintagmatis yang mengatakan bahwa penyebutan dua istilah (muslim dan mukmin) secara beriringan dengan disisipi partikel wawu menunjukan bahwa kedua istilah itu bukan merupakan sinonim-meskipun ada persinggungan makna-, tetapi memiliki sense (makna) dan reference (referensi) yang berbeda. Selain itu, penyebutan kedua istilah dalam ketiga ayat tersenut memberikan pengertian simbolis tentang tahapan eksistensi yang berbeda pula. ${ }^{32}$

Selanjutnya, Syahrur menyebutkan 9 ayat di dalamnya kata Islam atau turunannya diatributkan kepada umat-umat sebelum datangnya Nabi Muhammad. Pada QS. al-Jin: 14, QS. Āli 'Imrān: 67, QS. Yūsuf: 101, QS. al-A'rāf: 126, QS. Yūnus: 90, QS. Āli 'Imrān: 52, QS. Yünus: 42-43 dan QS. al-Dhāriyāt: 35-36 istilah al-muslimūn secara berturut-turut disandarkan pada komunitas Jin, Nabi Ibrāhim, Nabi Ya'qūb, Nabi Yūsuf, para penyihir masa Fir'aūn, keinginan Fir'aun menjadi seorang muslim, para pengikut Nabi Isa (alHawariyun), Nabi Nuh, Nabi Lüt. Menurutnya, hal ini memberikan pemahaman bahwa aksiden Islam bukan hanya milik umat Nabi Muhammad Saw.

Kaitannya dengan konsep Iman dalam al-Qur'an, Syahrur tampaknya jauh lebih berhati-hati dan seksama dalam menyikapai ayat-ayat yang menyebutkan kata iman dan turunannya. Metode intratekstualitas yang diaplikasikannya tampaknya bukan sekadar untuk memahami simbol linguistik al-Qur'an. Tetapi juga untuk memahami logika al-Qur'an yang inheren dalam ayat-ayatnya. Bagi Syahrur, kata Iman dalam al-Qur'an memiliki makna polivalen (lebih dari satu makna). Islam dalam sebagian ayat diartikan dengan Islam, dan pada sebagian ayat yang lain memiliki arti "beriman pada Nabi Muhammad Saw". Polivalensi makna ini disebabkan oleh kenyataan bahwa kedua istilah tersebut memiliki persinggungan potensi makna. Untuk menentukan potensi makna mana yang dikehendaki oleh suatu ayat, seseorang harus mencermati konteks dan logika ayat yang dimaksud. $^{33}$

\footnotetext{
${ }^{32}$ Abd. Mustaqim, Sahiron Syamsudin: Wacana Baru Berbagai Metodologi (Yogyakarta: Tiara Wacana Yogya, 2002).

3 Abdul Mustaqim, Sahiron Syamsuddin, "Studi al-Qur'an Kontemporer: Wancana baru berbagai Metodologi Tafsir", dalamMetode Intratekstualitas
} 
Bagi Syahrur, perangkat metodologis, ini memiliki justifikasi dari QS. al-Muzammil: 4. Pada ayat tersebut kata Tartīl yang menurutnya tidak diartikan dengan "membaca" (tiläwah) sebagaimana yang dipahami oleh mayoritas mufasir. Lafal tersebut diambil dari akar kata al-ratlyang dalam bahasa Arab berarti "barisan pada urutan tertetentu." Atas dasar ini, kata tartīl diartikan dengan "mengambil ayat-ayat yang berkaitan dengan satu topik dan mengurutkan sebagiannya di belakang sebagian yang lain."34

Berdasarkan berbagai uraian di atas masih ada celah bagaimana kajian ini dilakukan terutama dalam paradigma pemikiran Syahrur, yang kemudian diterapkan atas larangan pernikahan antar-agama dalam hukum Islam.

\section{Kajian Pustaka}

Sebenarnya kajian mengenai pernikahan antar-agama bukanlah hal yang baru lagi. Sudah banyak karya tulisan yang mengupas masalah ini, bahan dalam kitab-kitab klasik baik fiqih maupun tafsir. Namun pembahasan mereka hanya berkutat pada penghalalan dan pengharaman pernikhan tersebut. Hal tersebut masih bisa dimaklumi mengingat bahwa belum ada pengkajian khusus tentang bagaimana penerapan paradigma Syahrur atas pelarangan atas hukum pernikahan antar-agama tersebut.

Tesis dari Muhammad Zainal Abidin yang berjudul "Pandangan Muhammad Syahrur tentang "Islam dan Iman", tesis ini hanya mendeskripsikan serta menganalisis pemahaman pilar Islam dan Iman Syahrur dengan membandingkannya dengan gagasan lain seperti pemahaman Mukti Ali, Fazlurrahman. Tanpa mengaitkannya dengan permasalahan yang ada yakni pernikahan antar-agama.

Tesis yang ditulis oleh Tutik Hamidah dengan judul "Pernikahan antar-agama di Indonesia (perspektif Muslim) $)^{35}$ mengungkap latar belakang kenapa di Indonesia pernikahan antaragama dilarang. Dia menemukan larangan tersebut sangat dipengaruhi oleh ketegangan yang terjadi dalam hubungan antar-

Muhammad Syahrur dalam Penafsiran al-Qur'an (Tiara Wancana: Yogyakarta, 2002), 142.

${ }^{34}$ Muhammad Syahrur, al-Kitāo, wa al-Qur'ān: Qirā'ah Mu'āṣirah (Damaskus Dār al-Ahāīi, 1990), 197.

35 Tutik Hamidah, Perkawinan Antar-agama di Indonesia Perspektif Islam, Tesis, Tidak diterbitkan (Yogyakarta: Program Pascasarjanah IAIN Sunan Kalijaga Yogyakarta, 2000). 
agama khususnya dengan Kristen dan Katolik. Pada tesis ini misalnya belum jelas batasan hukumnya, hanya dalam satu sub babnya dia membahas pernikahan antar-agama bagi wanita muslim.

Tesis sejenis juga pernah ditulis oleh Mazroatus Saadah "Perkawinan Antar-agama dalam peraturan Perudang-undang pernikahan di Indonesia"36. Karya tersebut sudah sedikit lebih banyak membahas kenapa wanita dilarang untuk menikah dengan laki-laki non-Muslim. Namun penulisan tidak melihat ada nuansa pembaharuan dalam kajiannya. Dia lebih memfokuskan pembahasannya kepada peraturan perundang-undang Indonesia mengenai pernikahan antar agama. Akan tetapi, kajian historis tematiknya cukup memberikan informasi tentang latar belakang terlarangnya wanita muslim menikah dengan laki-laki non-muslim.

Suara yang sangat berani datang dari para intelektual muslim yang bergabung dalam penulisan Paradigmadina. ${ }^{37}$ Mereka membolehkan wanita menikah dengan laki-lai non-Muslim karena wilayah ini adalah ijtihădi yang terikat dengan konteks tertentu. Dan pada konteks sekarang ini dimana pluralitas sangat tidak bisa dihindarkan dan juga karena al-Qur'an memandang pluralitas agama merupakan agama merupakan sunnatullah, maka pernikahan antaragama bisa dijadikan wahana untuk membangun toleransi dan kesepahaman antara masing-masing pemeluk agama demi terciptanya karukunan dan kedamaian. Namun demikian, tidak didapatkan pembahasan yang komprehensif dan mendalam mengenai bagaimana proses pelarangan dan pembolehan pernikahan antar-agama dilihat dari term istilah yang masih tumpang tindih pada perdebatan makna hukumnya dalam istilah musyrik-kafir, Ahl al-Kitāb, Isläm-imān, dan lainnya.

\section{Kerangka Teoritik}

Pernikahan adalah salah satu bahasan dalam fiqh Islam. Meskipun al-Qur'an dan al-Sunnah telah menjelaskan secara rinci

\footnotetext{
${ }^{36}$ Mazroatus Saadah, Perkawinan Antar Agama dalam peraturan Perudangundang Perkawinan di Indonesia, Tesis. Tidak diterbitkan (Yogyakarta: Program Pascasarjana IAIN Sunan Kalijaga Yogyakarta, 2003).

37 Nurcholis Madjid, et.al, Fikih Lintas: Membangun Masyarakat InklusifPluralis (Jakarta: Paradigma, 2004), 164.
} 
mengenai pernikahan namun perkembangan zaman sudah berubah. Konsekuensinya pernikahan menemukan bentuknya yang berbeda dari zaman Nabi, Sahabat, maupun Tabi'in, demikian pula halnya mengenai pernikahan antar-agama. Untuk menerapkan hukum atas pelarangan pernikahan antar-agama dalam hukum Islam, perlu adanya metode dan pendekatan yang khusus.

Untuk menjawab permasalahan tersebut perlu dirumuskan dalam kembali, hal itu hanya bisa menggunakan paradigma Syahrur, yang menggunakan pendekatan normative-historis dan metode studi tematik-linguistik. Dalam artikel ini juga ditambahkan teori analisis yang berguna untuk mendapatkan pemahaman yang lebih konkrit yakni sebuah analisis diakronik-sinkronik dan sistem nilai (budaya).

Metode tematik-linguistik adalah sebagai pisau bedah untuk mencari kunci atas term atau istilah yang berkembang atas larangan pernikahan antar-agama. Dengan menggunakan metode termatik dapat ditemukan beberapa hal yakni,

Pertama: dapat menentukan masalah pokok yang dibahas dalam satu surat, Kedua. dapat menemukan ayat-ayat dalam surat tersebut yang membahas masalah pokok, Ketiga: dapat menemukan ayat-ayat yang membahas masalah tersebut dari surat lain.

Keempat. dapat menghubungkan semua ayat tersebut, baik yang bersumber dari surat yang sama maupun dari surat lain, dan Kelima: dapat menganalisis hubungan ayat-ayat yang membahas pokok masalah dengan ayat-ayat lain dalam surat tersebut. Semua ayat-ayat tersebut harus diseratkan dengan konteks masing-masing kalau memang ada. ${ }^{38}$ Sedangkan metode lingulistik adalah metode umum yang meliputi kaidah-kaidah menumpulkan teks secara umum dalam bahasa yang mencangkup studi fonologi dan penjelasan fungsi bahasa, yaitu sebagai media yang menampung makna pemikiran manusia (au'iyatun li al-ma'ānî̀), selain itu bahasa juga berfungsi sebagai sarana komunikasi dalam kehidupan.

Selain karakter yang bersifat umum, masing-masing bahasa juga memiliki ciri khas yang tampak pada karakter struktur suatu bahasa atau rumpun bahasa. Sehingga dapat dipahami bahwa ciri khas ini menunjukan relasi antar-tata bahasa dan pemikiran manusia. Bisa disimpulkan bahwa sejak pertumbuhan bahasa manusia, telah

\footnotetext{
${ }^{38}$ Al-Farmawi, Metode Tafsir Maudū',, 35 35-36.
} 
tercipta relasi antara bahasa, pemikiran, dan fungsinya sebagai sarana transmisi. ${ }^{39}$

Asumsi ini berdasarkan pada kenyataan bahwa sesungguhnya bahasa manusia, pada awalnya berupa ucapan logis (mantūqah). Konsekuensinya, bentuk pertama bsa harus berupa lafal yang mengungkapkan sebuah pemikiran dan memuat tujuan berkomunikasi.

Dari data sejarah manusia modern tampak bahwa pikiran manusia tidak tumbuh seketika. Fase perkembangan pemikiran manusia bertolak dari pengetahuan tentang objek konkret yang diperoleh dari indera pendengaran dan penglihatan. Fase ini mengalami penyempurnaan melalui pengetahuan terhadap objek abstrak. Proses yang sama dialami oleh perkembangan struktur lingustik yang tidak sempurna seketika. Dengan demikian, bahasa dan pemikiran tumbuh sempurna secara bersamaan struktur bahasa menyebabkan perbedaan struktur dalam berbagai bahasa. Konsekuensinya, sebuah bahasa atau rumpun bahsa memiliki karakter struktur yang berbeda.

Implikasi dari penggunaan metode tematik-linguistik yang digunakan untuk memahami paradigma Syahrur adalah dapat diterapkan atas larangan pernikahan antar agama dalam hukum Islam, karena memfokuskan kajian tematik nas dan pada relasi antara bahasa, pemikiran dan fungsi transmisi sejak awal pertumbuhan bahasa, yakni berpijak pada dua teori, yaitu: (1) sejak awal pertumbuhannya bahasa merupakan ujaran logis; (2) menolak sinonimitas (al-tarāduf) dalam bahasa Arab.

Sedangkan pendekatan normative-historis, berfungsi sebagai episteme dan wacana, artinya bagaimana cara manusia menangkap, memandang, memahami sesuatu fenomena dan bagaimana cara manusia membicarakan kenyataan. ${ }^{40}$ Menurut Michel cara Foucult (1926-1984), manusia pada tiap-tiap zaman menangkap kenyataan dengan cara tertentu atau dengan caranya sendiri-sendiri. Episteme dan wancana juga tunduk pada berbagai aturan yang menentukan apa yang dipandang atau dibicarakan dari kenyataan, apa yang dianggap penting dan tidak penting, hubungan apa yang diadakan antara

\footnotetext{
${ }^{39}$ Yang dimaksud transmisi di sini adalah proses penyampaian pesan kepada pihak lain atau disebut komunikasi.

${ }^{40}$ Muhammad Arkoun, Nalar Islam dan Nalar Modern: Berbagai Tantangan dan Jalan Baru (Jakarta:INIS, 1994), 21-22.
} 
berbagai unsur kenyataan dalam penggolongan dan analisis, dan seterusnya. Dengan kata lain, setiap zaman memandang, memahami dan membicarakan keyataan dengan cara yang berbeda-beda (dengan caranya sendiri-sendiri). ${ }^{41}$

Sebuah analisis diakronik-sinkronik dan sistem nilai (budaya) adalah bermaksud untu menelusuri sejarah dan berkembangan satu fenomena yang sedang diteliti dan mengintari fenomena yang sedang diteliti, di samping itu juga bermaksud mengetahui nilai budaya sang tokoh dimana dia hidup, dengan kata lain penelitian dengan teori diakronik-sinkronik dan system nilai (budaya) adalah penelitian yang menelusuri latar belakang dan perkembangan fenomena yang diteliti lengkap dengan sejarah sosio-historis dan nilai budaya yang mengitarinya.

Maka menjadi wajar pula kalau alat analisis ini lebih dikenal sebagai analisis sejarah atau sosial (sosiologi). ${ }^{42}$ Telah diketahui bahwa paradigma Syahrur tetap menggunakan al-Qur'an dan alSunnah. Sunnah dalam pandangannya, mewakili sebuah model metodologi hukum. Sunnah berbeda dengan al-Qur'an, tetapi alSunnah juga sama dengan al-Qur'an. Sunnah tidak menyediakan jalan metedologi (manhaj) untuk membangun sebuah sistem. Bagianbagian al-Sunnah yang demikian menurutnya adalah kondusif untuk menciptakan metodologi dan teori yang akan diambil sebagai sesuatu yang berdiri dari kehidupan pribadi Nabi dan sebagai sesuatu yang hidup pada masa Nabi.

Terlepas dari al-Qur'an dan ketetapan-ketetapan al-Sunnah yang relevan kepada teori ini, Syahrur menolak seluruh sumbersumber hukum lain yang usang dan menindas. Dia juga menjelaskan qiyās sebagai sesuatu yang menindas. Untuk penjelasan tersebut, bagaimana mungkin sebuah analog diambil dari ukuran dan peristiwa yang terjadi antara abad ketujuh dan kedua puluh?

Sungguh, sebuah penghargaan harus diberikan kepada Syahrur karena dia dapat melepaskan qiyas dengan menetapkan penggantinya dalam teori limit. Sejalan dengan itu, Syahrur juga mampu mematahkan ide ijmā' yang berlebih-lebihan karena epitemologinya, secara definitive, tidak memerlukan unsur kepastian. Hukum, dalam

\footnotetext{
${ }^{41}$ Muhammad Arkoun, Nalar Islam dan Nalar Modern: Berbagai Tantangan dan Jalan Baru (Jakarta:INIS, 1994), 22.

${ }^{42}$ Khoiruddin Nasution, Pengantar Studi Islam (Yogyakarta: ACAdeMIA+TAZZAFA, 2007), 152.
} 
pandangan Syahrur terus berubah, sepanjang hukum itu bergerak di antara batas-batas dan tidak keluar darinya. Konsep ijmā' yang ia akui hanyalah satu, yaitu ketika mayoritas penduduk memilih suatu hukum yang disepakati dan ketika uṣūl itu dipandangi sebagai hukum, maka mayoritas penduduk yang telah memilih tersebut harus bertanggungjawab terhadap implikasinya. Syahrur menegaskan bahwa ide ijma' tradisional bersifat dugaan (wahmî) dan tidak mengikat kaum Muslimin pada zaman modern. ${ }^{43}$

Dari keseluruhan usaha untuk merumuskan kembali teori hukum, pandangan-pandangan Syahrur hingga kini adalah yang paling menyakinkan. Puncak keberhasilan dari suatu metodologi hukum bergantung tidak hanya pada integritas intelektual dan tingkat kecanggihan dalam berteori akan tetapi bergantung juga pada kemungkinan pemberlakuan metodologi hukum baru yang ditawarkan Syahrur ini hingga kini masih asing bagi mayoritas umat Islam. Padahal, bukan saja metodologi tersebut telah disusun secara padu dan baik, tetapi juga metodologi tersebut lebih sesuai dengan sistem pemikiran yang Islami. Metodologi Syahrur tidak tunduk pada konsep yang dipahami secara tektual, namun ia memadukan analisis tekstual dan kontekstual untuk menepatkan sebuah hukum humanis yang memberikan panduan secara umum. Tegasnya, metodologi Syahrur tidak mau didikte secara literal dan tekstual oleh 'kehendak' wahyu. Berdasarkan pemikiran Syahrur yang meyakinkan tersebut, maka paradigma Syahrur yang kemudian bisa diterapkan atas larangan pernikahan antar agama dalam hukum Islam, sebagai tawaran dan solusi final dengan menggunakan metode dan pendekatan tersebut di atas.

\section{Metode Penelitian}

Penelitian ini adalah penelitian literature atau kepustakaan (library research) yang memakai metode tematik-linguistik, terhadap kitab-kitab suci baik al-Qur'an maupun hadis yang menginformasikan tentang pernikahan antar-agama dan hal-hal yang berkaitan dengannya, didukung oleh naskah-naskah klasik maupun kontemporer akan penulis kaji dan telah untuk mendapatkan pemahaman yang lebih mendalam dan bisa di pertanggung jawabkan secara teks maupun historis. Hal ini sejalan dengan obyek tulisan yaitu ingin

43 Muhammad Syahrur, al-Kitāb wa al-Qur'ān: Qirā'ah Mu'āṣirah (Kairo Damaskus: Sina lil al-Nasr, 1992), 474-475. 
mengetahui lebih kritis atas pemaknaan term/istilah yang berkembang dalam discourse larangan pernikahan antar-agama. Syahrur adalah tokoh fenomenal yang mana paradigma dan asumsi dasar pemikirannya bisa dijadikan dasar dalam tulisan ini, untuk mengetahui hal itu tentunya perlu mengkaji beberapa kitab yang telah dikarang oleh Syahrur. Adapun sumber informasi dalam tulisan ini terbagi dalam tiga trem yaitu: Trem pertama, berkaitan dengan bagaimana paradigma Syahrur terhadap term/istilah atas pelarangan pernikahan antar agama? Term yang kedua apa pengaruh konsep paradigma Syahrur terhadap pernikahan antar agama?Term yang ketiga bagaimana penerapan hukum atas pelarangan pernikahan antar-agama dalam hukum Islam? Dengan mengambil sumber informasi dari berbagai literatur yang bersifat primer maupun sekunder.

\section{Epilog}

Berdasarkan uraian dan kajian yang telah dipaparkan di atas, maka dapat disimpulkan bahwa selama ini kegelisahan atas pelarangan pernikahan antar-agama yang terjadi, kini sudah ada tawaran solutif dengan menggunakan paradigma Syahrur. Tawaran tersebut tetap mengacu pada al-Qur'an dan al-Sunnah yang mayoritas ulama dan pemikiran keislaman sepakat sebagai kunci dasar dan sumber utama dalam pembentukan diskursus hukum tentang pernikahan antar-agama dan menjadi panduan utama dalam menghasilkan ijtihad yang dipahami oleh ulama' tafsir dan fikih. Secara lebih spesifik dan mendalam, dapat dinyatakan bahwa setelah mengupas pemahaman dan paradigma Syahrur dan penerapannya atas pelarangan pernikahan antar agama dalam hukum Islam, hal itu Syahrur terlihat lebih obyektif dalam menjawab problematika hukum pernikahan antar agama ini. Sehingga dalam wilayah aplikasi hukum pengaruh paradigma Syahrur terhadap diskursus pernikahan antar agama akan menemukan momentumnya baik secara teoritis maupun fakta empiris, hal ini juga diharapkan bisa tercapainya suatu pemahaman yang dapat menjadi "jalan" dalam melihat pernikahan antar-agama, dengan tetap mengedepakan saran-saran, untuk sumbangsi tawaran dan solusi metodologis.

\section{Daftar Pustaka}


Abū Zayd, al-Nass, al-Suktah, al-laqiqh, Beirut: al-Marakaz al-Saqafi al'Arabi, 1995.

Arkoun, Muhammad, Nalar Islam dan Nalar Modern: Berbagai Tantangan dan Jalan Baru Jakarta: INIS, 1994.

A. Sirry, Mun'im, Fiqih Lintas Agama, Membangun Masyarakat Inklusif-Pluralis, Jakarta: Paradigma, 2004.

Al-Bukhārī, al-Jāmi’ al-Sahīh, Beirut: Dār al-Fikr, 1994.

Al-Dhahabī, M. Husayn, "al-Tafsīr wa al-Mufassirūn” Beirut: Dār alKutub al-Hadithah, 1961.

Al-Hana, Rudy, "Paradigma Hermeneutika Dalam Tafsir al-Qur'an" Qalita Ahsan, Vol. Viii, No. 1 April 2006.

Clark, Peter "The Shahrur Phenomenon: a Liberal Islamic Voice From Syiria" dalam Islam and Christian Muslim Relations. Vol.7,No. 3,1996.

Hamidah, Tautik, Perkawinan Antar Agama di Indonesia: Perspektif Islam, Yogyakarta: Program Pasca Sarjana IAIN Sunan Kalijaga Yogyakarta, 2000.

J. Waardenburg, "World Religions as Seen in The Light of Islam", dalam A.T.Welch dan P.Cachi, ed., Islam:Past Influence and Present Challenge, Edinburgh:Edinburgh University Press, 1979.

Ja'far dan Albab, “al-Minhāj al-Lughawì fi al-Kitab dalam Muhammad Syahrur: al-Kitab wa al Qur'an: Qira'ah Mu'asirah, Damaskus: al-AhāTi li al-Tibā'ah wa al-Nasr wa al-Tauzi'',1992.

Al-Khū̄i, Amīn, "Manāhij Tajdìd fí al-Balāghah wa al-Tafsīr wa alAdab"Kairo: Dār al-Ma'rifah, 1961.

Al-Maududi, Abū al-A'lā, al-Islām fī Muwājahah al-Tahaddiyah alMu'āsirah, Kuwait: Dār al-Qalam,1983.

Madjid, Nurcholis, et.al,Fikih Lintas: Membangun Masyarakat Inklusif-Pluralis, Jakarta: Paradigma 2004.

Al-Munjid, Mahir, "al-Ishkāliyyah al-Manāhijiyyah fī al-Kitāb wa alQur'ān” Dirāsah Naqdiyyah, dalam 'Alam al-Fikr.t.tp., t.th.

Muhami, Munir Muhammad Ṭāhir al-Shawwāf. "Tahāfut al-Qirā'ah al-Mu'āsirah"Cypruss: al-Sawwaf, 1993.

Mustaqim, Abdul, Sahiro Syamsuddin, "Studi al-Qur'an Kontemporer: Wancana Baru Berbagai Metodologi: Tipologi dan Proyeksi Penafsiran Kontemporer terhadap al-Qur'an" dalam jurnal Studi Ilmu-ilmu al-Qur'an dan Hadits Vol 8, No.2, Juli 2007. 
Mustaqim. Abdul, Sahiro Syamsudin: "Wancana Baru Berbagai Metodologi”Yogyakarta: Tiara Wancana Yogya, 2002.

Nasution, Khoiruddin, Pengantar Studi Islam, Yogyakarta: ACAdeMIA+TAZZAFA, 2007.

Al-Rāzì, Fakhruddin. Tafsir al-Fakhr al-Razi al-Musytahar bi alTafsir al-Kabïr wa Mafätih al-Ghaib, dikomentari oleh Shaikh Khalil Muhyiddin al-Mays, Beirut: Dār al-Fikr, 1995.

Saadah, Mazroatus, Perkawunan Antar Agama dalam Peraturan Perundang-Undang di Indonesia, Yogyakarta: Program Pascasarjana IAIN Sunan Kalijaga Yogyakarta, 2003.

Sadari, Hukum Pernikahan yang Diperbandingkan: Rekontekstualisasi Pemikiran dan Metodologi Hukum Keluarga Islam, cet. ke-1 Pondok Cabe Tangsel: CV. Iqralana, 2018.

Reorientasi Hukum Keluarga Islam, cet. ke-1, Pondok Cabe Tangsel: CV. Iqralana, 2017.

--------. Konsepsi Pernikahan Relevansi Antara Agama dan Keberagamaan: Refleksi Pemikiran Hukum Keluarga Islam, cet. ke-1, Pondok Cabe Tangsel: CV. Iqralana, 2018.

Suhadi. Kawin Lintas Agama: Perspektif Kritik Nair Islam, Yogyakarta, LKis, 2006.

Syahrur, Muhammad. Al-Kitāb wa al-Qur'ān: Qirā'ah Mu'āsirah, Kairo dan Damaskus: Sina li al-Nashr, 1992.

-------. "Prinsip dan dasar Hermeneutika al-Qur'an Kontemporer" terj. Sahiron Samsuddin, dkk Yogyakarta: eLSAQ Press, 2004.

-------. al-Islām wa al-İmān: Manzūmāt al-Qiyam, Damaskus alAhāTi li al-Ṭibā'ah wa al-Nashr wa al-Tawzì', 1996.

Nahw Ușūl al-Jadidah li al-Fiqh al-Islämī, Damaskus: alAhāli li al-Tibā'ah wa al-Nashr wa al-Tauzì', 2000.

Syamsyuddin, Sahiron. "Konsep Wahyu al-Qur'an dalam Perspektif

M.Shahrur", dalam jurnal Studi Ilmu-ilmu al-Qur'an dan Hadits.Vol. I. No.I, Juli 2000.

Al-Ṭāibī, 'Iyyal Allah, Tunisis: Saras li al-Nashr, 1992. 